\title{
ALUMÍNIUM LEMEZ ASZIMMETRIKUS HENGERLÉSE KÖZBEN FELLÉPÕ DEFORMÁCIÓJÁNAK VIZSGÁLATA
}

\author{
Bátorfi János György ${ }^{a}$, Sidor Jurij ${ }^{b^{*}}$
}

${ }^{a}$ ELTE, Informatikai Kar, Savaria Múszaki Intézet, Gépészmérnöki MSc, 2. évf.

${ }^{b}$ ELTE, Informatikai Kar, Savaria Müszaki Intézet, egyetemi tanár

\begin{abstract}
ABSZTRAKT
Ebben a cikkben a hengerek közötti szimmetrikus és aszimmetrikus hengerlés deformációs viszonyait vizsgáltuk. Lemezek esetén az egyenletes keménység és feszültségeloszlás aszimmetrikus hengerléssel érhető el. A kialakuló deformációk és alakváltozások vizsgálatához a keresztmetszet pontjainak egymáshoz képesti relatív elmozdulásainak ismerete szükséges. A lemez és a henger közötti súrlódási tényező különböző modellekkel vizsgálhatóak. Hengerelt alumínium mintákból határoztuk meg az egyes pontok elmozdulását, melyekból az adatok feldolgozásával számítottuk a hengerlés közben fellépô súrlódási tényezőt. A mérési pontok elmozdulását a keménységmérési nyomokról készített hengerlés előtti és utáni optikai mikroszkópos felvételek összehasonlításával végeztük. A mintákból kinyert adatok és a végeselemes szimuláció eredményeinek összehasonlításával ellenôriztük a modellek alkalmazhatóságát.
\end{abstract}

Kulcsszavak: aszimmetrikus hengerlés, deformáció, súrlódás

\section{Bevezetés}

Hengerlés során az anyag képlékeny alakváltozást szenved el, a lemez magassági, hosszúsági és szélességi méretei megváltoznak. Továbbá megváltozik a hengerelt anyag szerkezete és tulajdonságai is [1]. A hengerlés során fóként a lemez hosszúsága és vastagsága paraméterei változik meg, a szélesség változása elhanyagolható, így a végeselemes modellezés során a lemez hengerlése egyszerüsítve, $2 \mathrm{D}$-s alakváltozásként modellezhető. A hengerlésre használható legfóbb jellemzố a vastagság változásból meghatározható deformáció, mely az (1) egyenlet szerint számítható.

$$
\varepsilon=\frac{\Delta h}{h_{0}}=\frac{h_{0}-h_{d e f}}{h_{0}}
$$

ahol: $\quad-\varepsilon$, a jellemzố deformáció,

- $\Delta h$, vastagság változás,

- $h_{0}$, vastagság hengerlés előtt,

- $h_{\text {def }}$, vastagság hengerlés után.

A hengerlés során a hengerrel érintkezô felület vízszintes vetületének hossza az [1]-ben ismertetett (2) egyenlet szerint számítható.

$$
l_{d}=\sqrt{R \cdot \Delta h}
$$

ahol: $\quad-l_{d}$, a nyomott ív vízszintes vetülete (1. ábra),

- $R$, a henger sugara.

(C) ELTE, Informatikai Kar, Savaria Múszaki Intézet, 2020

*Kapcsolattartó: js@inf.elte.hu

https://doi.org/10.37775/EIS.2020.1.1 
A hengerlés sikerességéhez a hengerlési paramétereknek az [1]-ben ismertetett behúzási és áthúzási feltételeket ki kell elégíteni, a feltételeket a (3) és a (4) összefüggések adják meg. A hengerlési feltételek értelmezése az 1. ábrán látható.

A behúzási feltétel:

$$
\operatorname{tg} \alpha=\frac{2 l_{d}}{2 R-\Delta h}<\mu
$$

ahol: $\quad-\alpha$, a behúzási szög,

- $\mu$, súrlódási tényezô.

Az áthúzási feltétel:

$$
\operatorname{tg} \varphi=\frac{\Delta h}{2 l_{d}}<\mu
$$

ahol $\varphi$, az áthúzási szög.

A $\mu$ értékétôl függően három eset lehetséges:

$-\mu<\operatorname{tg} \alpha$ : A hengerlés nem lehetséges.

- $\operatorname{tg} \alpha<\mu<\operatorname{tg} \varphi$ : A hengerlés kezdetén a lemez hengerrésbe juttatásához külső erô alkalmazása szükséges.

- $\operatorname{tg} \varphi<\mu$ : A hengerlés külsó eróbevezetés nélkül lehetséges, a hengerek behúzzák a lemezt.

A lemez szélességi méretének változása az [1]-ben ismertetett (5)-(7) összefüggések segítségével lehetséges. Azonban az ezekból számítható alakváltozás a vastagságból adódó alakváltozáshoz képest elhanyagolható mértékú. Az ismertetett összefüggések tetszóleges anyagra alkalmazhatóak.

$$
\begin{aligned}
& \Delta b=0,35 \cdot \Delta h, \\
& \Delta b=0,35 \cdot l_{d} \cdot \frac{\Delta h}{h_{0}}, \\
& \Delta b=\frac{\Delta h}{3} .
\end{aligned}
$$

A lemez képlékeny alakváltozáshoz tartozó feszültség függ a deformáció mértékétól, a deformációs sebességtől, alakítás hőmérsékletétól, a függés az [1]-ben ismertetett (8) egyenletból határozható meg:

$$
k_{f}=k_{0} \cdot K^{\varphi} \cdot K^{\dot{\varphi}} \cdot K^{T},
$$

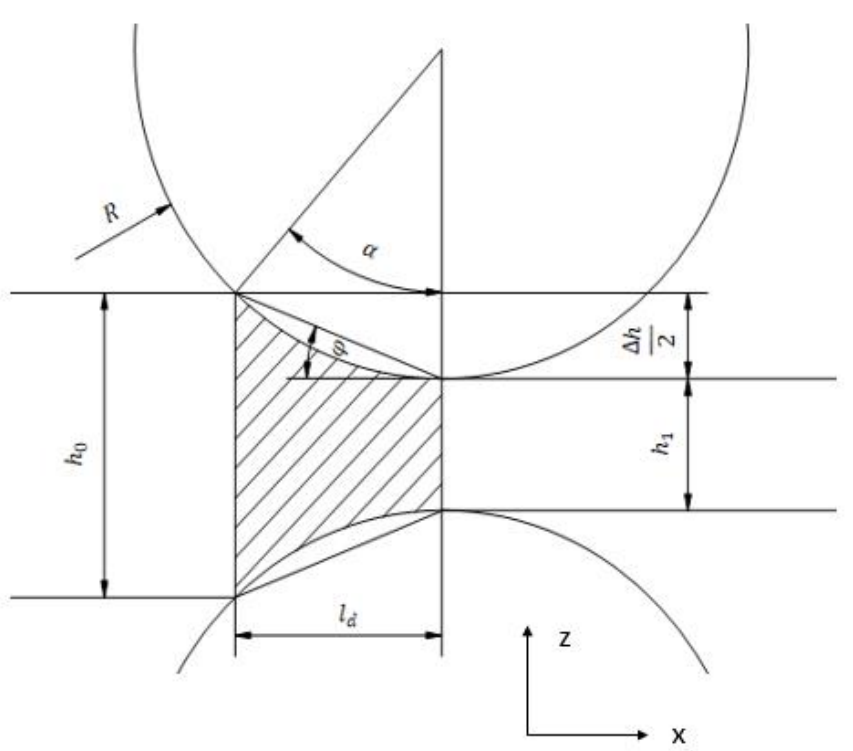

1. ábra: Hengerlési rés geometriai modellje 
ahol: $\quad-k_{f}$, az alakítási szilárdság,

- $k_{0}$, anyagfüggó állandó,

- $K^{\varphi}$, alakváltozás nagyságától függó tag,

- $K^{\dot{\varphi}}$ alakváltozási sebességtôl függó tag,

- $K^{T}$ alakítási hômérséklettől függő tag.

A (8) összefüggésben szereplő $k_{f}$ alakítási szilárdság a Tresca-Mohr (9) vagy a Huber-Mises-Hencky elmélet (10) szerint számítható.

$$
\begin{aligned}
k_{f} & =\sigma_{1}-\sigma_{3}, \\
k_{f} & =\sqrt{\frac{1}{2}\left[\left(\sigma_{1}-\sigma_{2}\right)^{2}+\left(\sigma_{2}-\sigma_{3}\right)^{2}+\left(\sigma_{3}-\sigma_{1}\right)^{2}\right]},
\end{aligned}
$$

ahol: $\quad-\sigma_{1}$, legnagyobb fófeszültség,

- $\sigma_{2}$, közepes föfeszültség,

- $\sigma_{3}$, legkisebb föfeszültség.

Az egyenértékú alakváltozás $(\bar{\varphi})$ Huber-Mises-Hencky elmélet szerint a (11) összefüggéssel számítható. A késóbbi számítások során a Huber-Mises-Hencky elméletet használtuk fel.

$$
\bar{\varphi}=\frac{2}{\sqrt{3}} \sqrt{\left(\varphi_{1}-\varphi_{2}\right)^{2}+\left(\varphi_{2}-\varphi_{3}\right)^{2}+\left(\varphi_{3}-\varphi_{1}\right)^{2}}
$$

ahol: $\quad-\varphi_{1}$, legnagyobb fốnyúlás,

- $\varphi_{2}$, közepes fönyúlás,

- $\varphi_{3}$, legkisebb fönyúlás.

Az alakítási szilárdság az [1] és [2] szerint (12) és (13) szerint számítható, mivel a hidegalakítás esetén az alakítási szilárdság nem függ az alakítási sebességtől és az alakítás hőmérsékletétől.

$$
\begin{aligned}
& k_{f}=R_{p 0.2}+B \cdot \bar{\varphi}^{n}, \\
& k_{f}=C \cdot \bar{\varphi}^{n},
\end{aligned}
$$

ahol: $\quad-R_{p 0.2}$, egyezményes folyáshatár,

- $B, C$, anyagfüggó állandó,

- $n$, keményedési kitevố.

A henger és a hengerelt lemez közötti súrlódási tényezô a [3] eredményei alapján függ a felületi nyomástól, csúszási sebességtől, hőmérséklettől, a (14) összefüggés szerint. Széles körben egyszerüsített számítást szoktak alkalmazni, melyeket a (15)-(17) egyenletek mutatnak be. A legegyszerúbb változat a (15) összefüggés szerinti, ahol a súrlódási tényezôt állandónak feltételezhetjük. A (17) egyenlet szerinti másik modell a csúszási sebesség változását veszi figyelembe [3] eredményei alapján.

$$
\begin{aligned}
\mu & =f(p, v, T) \\
\mu & =\mu_{0} \\
\mu & =C_{1}\left(C_{2}-0.0005 T-0.0056 v\right), \\
\mu & =\mu_{0} \frac{2}{\pi} \operatorname{arctg}\left(\frac{\Delta v}{C}\right)
\end{aligned}
$$


ahol: $\quad-\mu$, súrlódási tényezô,

- $\mu_{0}$, nyugvásbéli súrlódási tényezô,

- $p$, a felületek között fellépő nyomás,

- $v$, felületek közötti relatív csúszás sebessége,

- T, súrlódó felületek hômérséklete

- $C_{1}, C_{2}$ konstans.

A súrlódási folyamat elemzésének egy másik módja annak vizsgálata, hogy a súrlódásból származó csúsztatófeszültség nem haladhatja meg az anyagra jellemzô maximális csúsztatófeszültséget.

Az aszimmetrikus hengerlés jellemzője, hogy a két henger átmérője különböző, valamint az alsó és felső a hengernél eltér a hengerlési sebesség, vagy a súrlódási tényező. Ezért a szimmetrikus hengerlés során jellemzố nyomó alakváltozás mellett jelentôs mértékú csúsztató alakváltozás is éri az anyagot. Ez a [4] eredményein alapuló 2. ábrán is látható, valamint az is megfigyelhetô, hogy aszimmetrikus hengerlés esetén szinte egyenletes deformáció érhető el [5].

Jelen vizsgálat célja az alumínium lemezek szimmetrikus- és aszimmetrikus hengerlése során fellépô deformációk vizsgálata különös tekintettel az aszimmetrikus hengerlés során fellépô, jelentôs mértékû nyírási alakváltozásra. A cikkben elsôsorban a súrlódási tényezố és alkalmazott hengerlési paraméterek hatását vizsgáltuk a megmunkálás során fellépó deformációkra. A vizsgálat eredményei a késóbbiekben felhasználhatók a hengerlés egyszerúbb és hatékonyabb leírására, a hengerelt lemezben fellépő szerkezeti változások vizsgálatához.

\section{Anyag és módszer}

A hengerelt minták előkészítése és a mérések az Eötvös Loránd Tudományegyetem, Informatikai Kar, Savaria Múszaki Intézetének anyagvizsgáló laborjában történtek. A vizsgálatok minden esetben hideghengerléssel történtek. A hengermú alsó és felső hengerei külön szinkronmotorral hajtottak, a hengerek fordulatszáma frekvenciaváltóval külön-külön szabályozható. A hengerek átmérôje 150 mm. A hengerlési rés mérete önzáró mechanizmussal beállítható. A hengerlés során kenóanyagot nem alkalmaztunk. A hengerlések részben szimmetrikus hengerléssel, részben eltérô arányú aszimmetrikus hengerléssel történtek. A hengerelt lemezek anyaga Al 1050 és Al 6082 anyagminőségú alumínium.

Általános cél az egyenletes keménység és alakváltozás elérése a lemez vastagsága mentén, erre legalkalmasabb az aszimmetrikus hengerlés. A deformációk meghatározása az elmozdulások vizsgálatával lehetséges. Az elmozdulások meghatározására külön figyelmet kell fordítani, az adatok kinyerése optikai mikroszkópon készített felvételekból történt.

A hengerlési kísérletek eredményeit végelemes szimulációkkal (VEM) hasonlítottuk össze. A hengerlés végeselemes modellezéséhez szükséges a lemez és henger között fellépő súrlódási tényezô ismerete. Ennek meghatározása az elvégzett lemezek elmozdulásaiból történt. A valódi és VEM módszerrel meghatározott elmozdulásokra függvényt illesztve a deformációk bármely tetszóleges pontban meghatározhatók. A minták megfelelő elókészítésével a hengerelt lemez mélyebb rétegei is vizsgálhatóvá válnak. Az elôkészítés során a megfelelő méretű munkadarabokat hôkezelés után egyre finomabb csiszoló papírokkal simára csiszoltuk. A polírozás során a megmaradt finomabb karcok is eltûntek a minta felületéról.
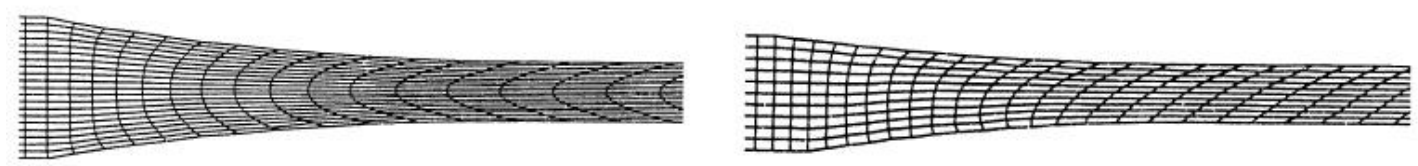

2. ábra: Hengerelt anyag keresztmetszete szimmetrikus és aszimmetrikus hengerlés esetén [4] 


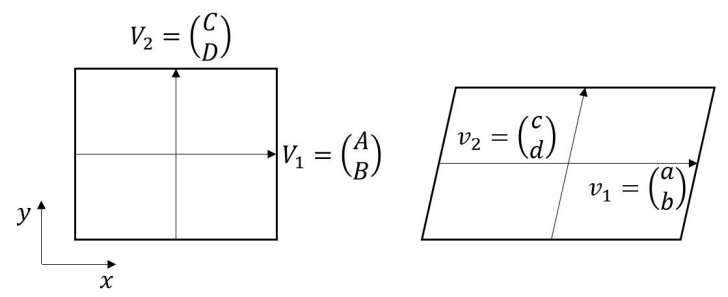

3. ábra: Elemi téglalapok deformáció előtt és után

A fémes anyagok keménységének mérése különböző módszerekkel történhet. A legszélesebb körben alkalmazott módszerek: Vickers, Brinell, Rockwell, Knoop. A változások mérésére mikrokeménységmérési módszereket alkalmaztunk, amivel a hengerelt lemez vastagsági mérete mellett 15-20 pontban is mértük a keménységet. A keménység változása alapján a keménységi profil megállapítható. A Zeiss Axio Imager A2.m anyagvizsgáló mikroszkóp segítségével készült képekból ImageJ szoftver 1.52p verziójának segítségével nyertük ki a pontok elmozdulását.

\section{Kísérleti eredmények}

A szimmetrikus hengerléssel jelentős alakítási energia vihető be. Az aszimmetrikus hengerlés hátránya, hogy hengerlés során a lemez meggörbül. A keresztmetszet vizsgált pontjaihoz tartozó deformáció és deformációs sebesség értékek kiszámításához egy-egy elemi téglalap vizsgálata szükséges. Ezen elemi téglalapok deformációinak kiszámítására [6] ismertet egy módszert. A 3. ábrán látható elemi téglalap egy idôpillanatában a deformációs gradiens tenzor meghatározása (18-22) összefüggések szerint lehetséges. A deformáció elôtti téglalapot leíró vektorok komponenseinek meghatározása a (18-19) összefüggések szerint történik [6].

$$
\begin{aligned}
& \mathbf{V}_{\mathbf{1}}=A \mathbf{i}+B \mathbf{j}, \\
& \mathbf{V}_{\mathbf{2}}=C \mathbf{i}+D \mathbf{j},
\end{aligned}
$$

ahol: $\quad-\mathbf{V}_{\mathbf{1}}, \mathbf{V}_{\mathbf{2}}$, vektorok kiinduló állapotban,

- $A, B, C, D$, kiinduló vektorok komponensei.

A deformáció utáni téglalapot leíró vektorok komponenseinek meghatározása a (20-21) összefüggések szerint történik [6].

$$
\begin{aligned}
& \mathbf{v}_{\mathbf{1}}=a \mathbf{i}+b \mathbf{j}, \\
& \mathbf{v}_{\mathbf{2}}=c \mathbf{i}+d \mathbf{j},
\end{aligned}
$$

ahol: $\quad-\mathbf{v}_{\mathbf{1}}, \mathbf{v}_{\mathbf{2}}$, vektorok hengerlés utáni állapotban,

- $a, b, c, d$, vektorok komponensei hengerlés után.

A (18-21) egyenletekból [6] szerint a deformációs gradiens mátrix a (22) összefüggés szerint számítható.

$$
\left[\begin{array}{ll}
a & b \\
c & d
\end{array}\right]=\boldsymbol{F}\left[\begin{array}{ll}
A & B \\
C & D
\end{array}\right] \longmapsto \boldsymbol{F}=\left[\begin{array}{ll}
a & b \\
c & d
\end{array}\right] \cdot\left[\begin{array}{ll}
A & B \\
C & D
\end{array}\right]^{-1}
$$

ahol $\boldsymbol{F}$ a deformációs gradiens mátrix. A deformációs sebességek meghatározása a gradiens mátrix elemeiból a (23) összefüggéssel lehetséges.

$$
\boldsymbol{L}=\dot{\boldsymbol{F}} \cdot \boldsymbol{F}^{-1} \approx \frac{\boldsymbol{F}}{\Delta t} \cdot \boldsymbol{F}^{-1},
$$

ahol $\boldsymbol{L}$, a deformációs sebesség mátrix. 


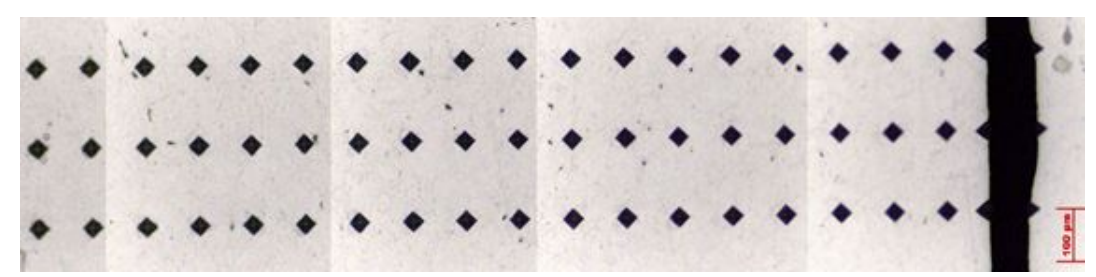

4. ábra: 1. minta keménységmérési nyomairól készült felvétel hengerlés elôtt, világos látótérben

A keménységi profilt 3 függóleges vonalon, egy vonal mentén 27 pontban mértük. A keménységmérési pontok eloszlására példa a 4. ábrán látható. A keménységmérési pontok a hengerlés során egymáshoz képest elmozdulnak, az elmozdulásokból az alakváltozások kiszámíthatók. A hengerelt lemezek elmozdulásait a végeselemes modellezés eredményeivel összevetve meghatározható a hengerek és a lemez közötti súrlódási tényezó.

A keménységméréséhez Zwick Roell ZHV $\mu$ Micro hardness tester keménységmérôt használtunk, 10-es nagyítás és $0,005 \mathrm{~kg}$ terhelés, valamint 10 másodperc mérési idő mellett. A felületekról Zeiss Axio Imager A2.m mikroszkóppal készítettünk felvételeket.

A kezdeti keménység profilra példa az 5. ábrán látható. Az értékekre másodfokú függvény illeszthetô. A mérések alapján az Al6082 minták átlagos keménysége 54HV, az Al1050 mintáké pedig 26 HV. Az adatok kinyerését nehezítették a deformáció során a keménység mérési nyomainak éles sarkából kiinduló repedések. Ezeket a kiugró értékeket a további feldolgozás során nem vettük figyelembe. A mérés a képeken felismerhetô Vickers keménységmérési nyomokra illesztett téglalapokkal történt. Az ImageJ szoftverbôl pontosvesszővel elválasztott szövegfájlként nyerhetôk ki a felismert téglalapok középpontjainak adatai, melyekre függvény illeszthetô. A hengerelt lemezekról készült mikroszkópos felvételre példa a 6 . ábrán látható.

A feldolgozás lépései:

- Színes felvétel szétbontása szín csatornák szerint.

- Felvétel bináris képpé alakítása (threshold funkcióval).

- Alakzatok és a bennfoglaló téglalapok középpontjainak exportálása .csv fájlba.

- Téglalapok szürése, manuális szúrése és eltolása az ábrázoláshoz.

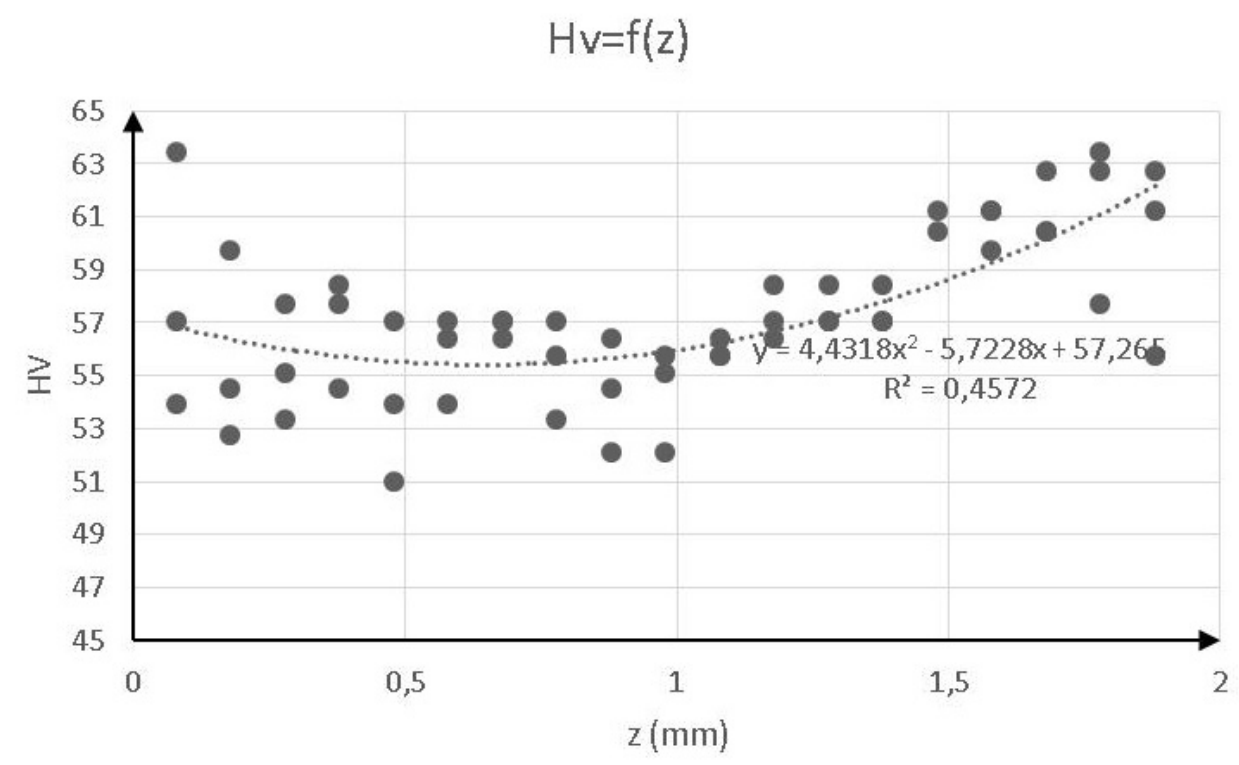

5. ábra: 1. minta keménységértékei a lemezvastagság függvényében hengerlés előtt 


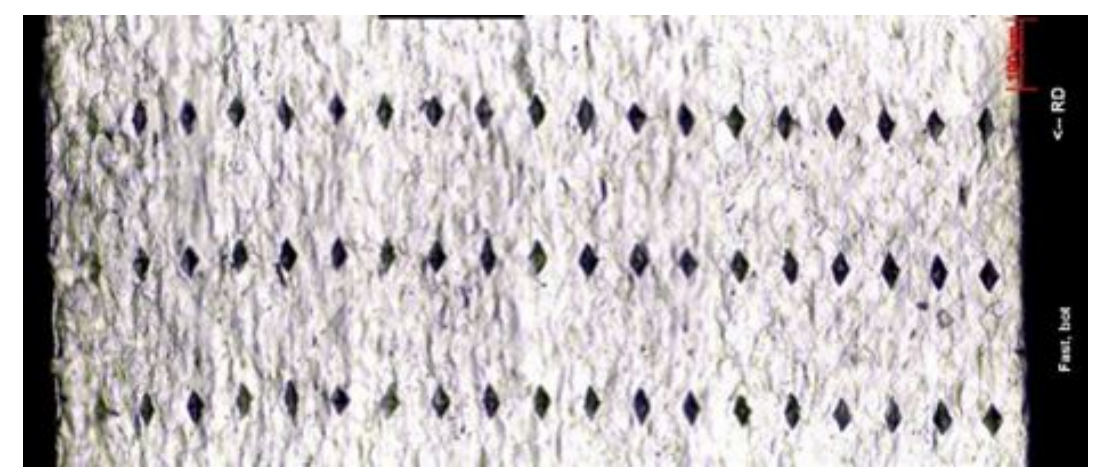

6. ábra: 5. mintáról készült mikroszkópos felvétel

A különbözô pontok elmozdulásának ismeretében a pontok elmozdulásaiból (24)-(26) összefüggések segítségével meghatározható a különbözô irányú normál- és csúsztató deformációk nagysága. A deformációk ismeretében a deformációs mátrix sajátértékeiként kapjuk a főnyúlásokat. A főnyúlások ismeretében a Huber-Mises-Hencky elmélet segítségével egyenértékú deformáció határozható meg.

Különbözô irányokhoz tartozó deformációk nagysága $\left(\varepsilon_{x}, \varepsilon_{z}\right.$ fajlagos nyúlások, $\gamma_{x z}$ pedig jellemző szögtorzulás):

$$
\begin{aligned}
\varepsilon_{x} & =\frac{h_{0}}{h}-1, \\
\varepsilon_{z} & =\frac{h-h_{0}}{h_{0}}, \\
\gamma_{x z} & =\frac{d x}{d z} .
\end{aligned}
$$

A redukált deformáció meghatározásához felhasználható, hogy az $x$ irányú deformáció elhanyagolható, mivel a henger korlátozza a tengelyével párhuzamos elmozdulást.

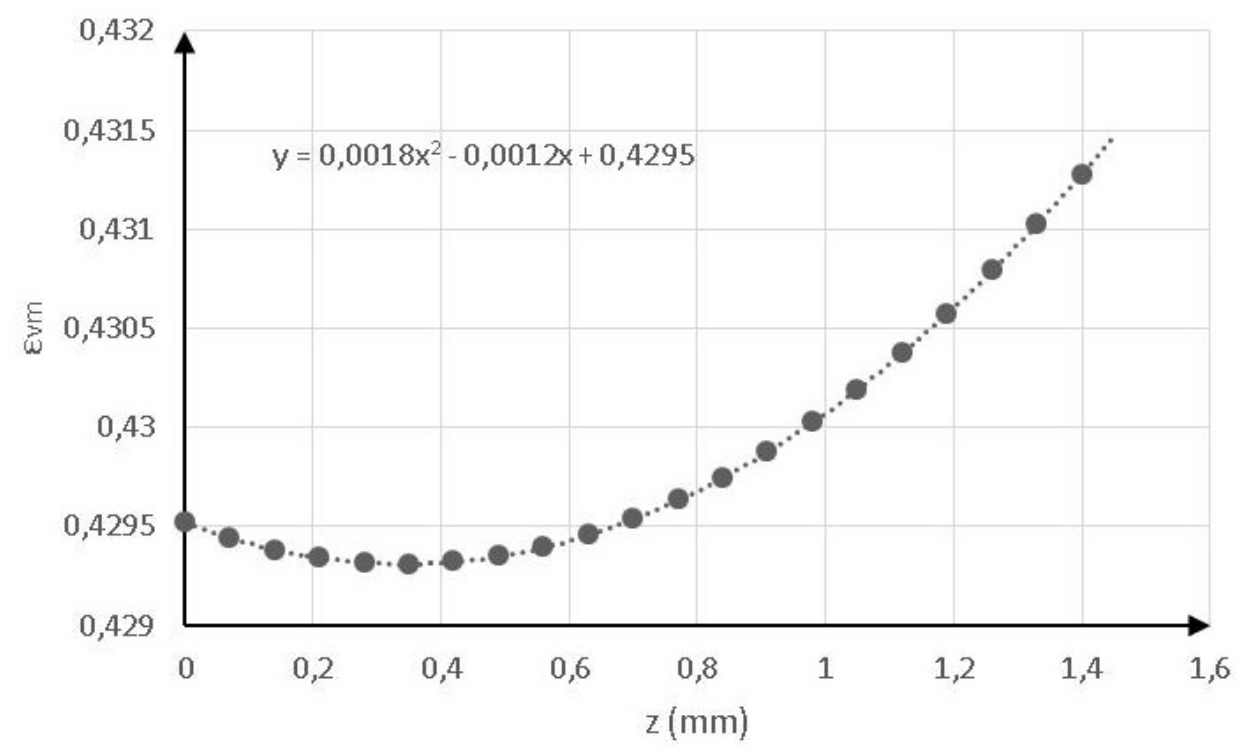

7. ábra: 5. minta $x$ irányú von Mises szerinti redukált deformációja a vastagság menti pozíció függvényében 


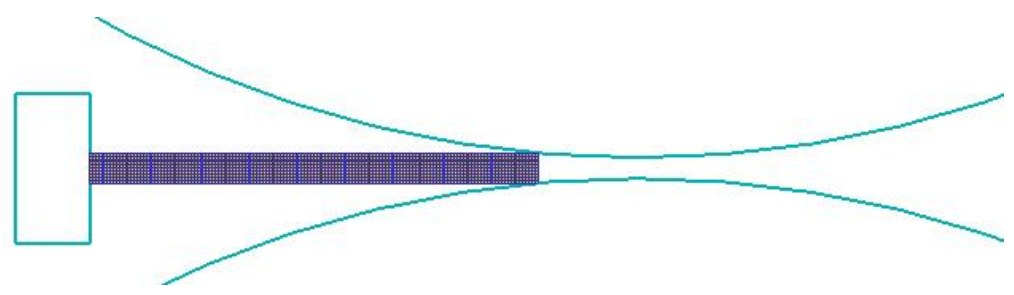

8. ábra: Végeselemes modellezéshez használt geometria

A deformációk mátrixban ábrázolva:

$$
\boldsymbol{A}=\left[\begin{array}{ccc}
\varepsilon_{x} & 0 & \frac{1}{2} \gamma_{x z} \\
0 & 0 & 0 \\
\frac{1}{2} \gamma_{x z} & 0 & \varepsilon_{z}
\end{array}\right] .
$$

A deformációs mátrixból a mátrix sajátértékeivel meghatározhatók a fốdeformációk, melyból (28) szerint egyenértékủ deformáció számítható. Redukált feszültségek a fóirányokhoz tartozó deformációk ismeretében:

$$
\varepsilon_{e q, V M}=\sqrt{\frac{2}{9}\left[\left(\varepsilon_{1}-\varepsilon_{2}\right)^{2}+\left(\varepsilon_{2}-\varepsilon_{3}\right)^{2}+\left(\varepsilon_{3}-\varepsilon_{1}\right)^{2}\right]} .
$$

A deformációk vastagság menti eloszlására példa a \% ábrán látható. A többi minta eredménye alapján belátható, hogy szimmetrikus hengerlés esetén a lemezben közel szimmetrikus deformáció eloszlás lép fel, aszimmetrikus hengerlés esetén pedig az aszimmetria nagyságától függóen a minimális deformáció értéke a lassabb sebességủ henger felé tolódik el. A hengerlés során fellépő súrlódási tényezô meghatározására végeselemes modellezést alkalmaztunk. A gyorsabb számítás miatt kétdimenziós, síkalakváltozási modellt feltételeztünk.

1. táblázat: AL-1100 és AL-6063 lineáris viselkedését leíró paraméterek

\begin{tabular}{|l|c|} 
Paraméter & Érték \\
\hline$E[\mathrm{MPa}]$ & 68900 \\
$\nu[-]$ & 0,33
\end{tabular}

2. táblázat: AL-1100 folyási görbéjének felhasznált értékei

\begin{tabular}{|c|c|c|}
$\varepsilon[-]$ & $\dot{\varepsilon}[1 / \mathrm{s}]$ & $\sigma[\mathrm{MPa}]$ \\
\hline 0 & 1 & 40 \\
0,2 & 1 & 73,975 \\
1 & 1 & 119,31 \\
2 & 1 & 123 \\
0 & 100 & 41 \\
0,2 & 100 & 76 \\
1 & 100 & 121 \\
2 & 100 & 125
\end{tabular}

3. táblázat: AL-6063 folyási görbéjének felhasznált értékei

\begin{tabular}{|c|c|c|}
$\varepsilon[-]$ & $\dot{\varepsilon}[1 / \mathrm{s}]$ & $\sigma[\mathrm{MPa}]$ \\
\hline 0 & 1 & 80 \\
0,09 & 1 & 99,832 \\
0,82 & 1 & 169,665 \\
2 & 1 & 173 \\
0 & 100 & 81 \\
0,09 & 100 & 10,832 \\
0,82 & 100 & 171,655 \\
2 & 100 & 175
\end{tabular}




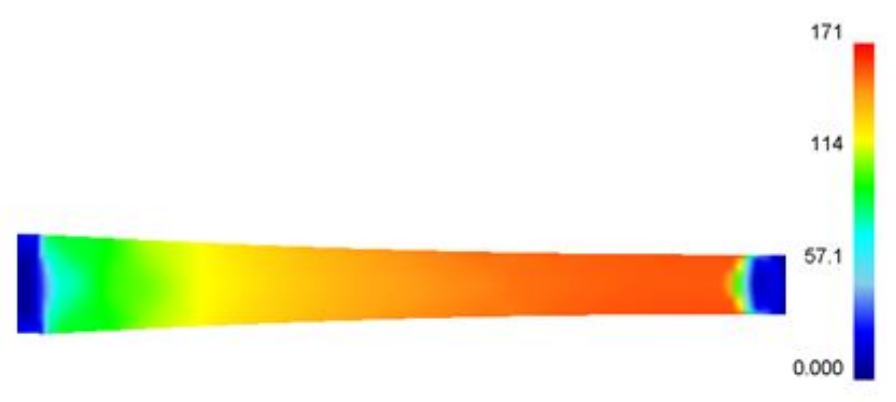

(a)

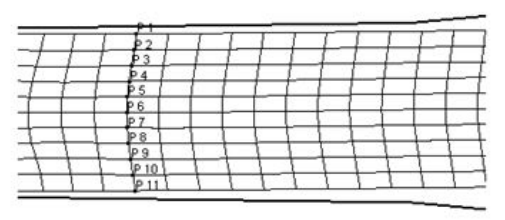

(b)

9. ábra: a) Redukált feszültség értékek rögzített paraméterek mellett MPa-ban, b) Vizsgált pontok

\section{VEM eredmények és adatok kinyerése}

A modell összeállítása során a hengereket végtelenül merevnek (rigid body) tekintettük a modellben. Ez az egyszerúsítés nem okozott jelentôs hibát a késóbbi számításokban. A lemez anyagaként Al1050 és Al-6082 helyett ezekhez hasonló viselkedést mutató, az alkalmazott szoftverben megtalálható "AL-1100" és "AL-6063" nevû anyagmodelleket definiáltuk. A szimuláció lépéseinek meghatározása idő alapon történt, az idő nagysága lépésenként $0,01 \mathrm{~s}$. Az összeállított geometriai modell a 8. ábrán látható.

A vizsgált geometria hengerlés előtti magassága $2 \mathrm{~mm}$, hossza $30 \mathrm{~mm}$. Hengerek átmérője $150 \mathrm{~mm}$. A hengerek fordulatszáma, a munkadarab végső magassága, és a henger-munkadarab közötti súrlódási tényezô szimulációként eltérô. A hálózás egyenlő elemméretű szabályos négyzethálóval történt, a munkadarab vastagsága mentén 10-20 elemre bontottuk fel azt. A szimuláció eredményeként ezen csomópontokhoz tartozó deformáció-, elmozdulás- és feszültség- értékeket nyertük ki a szoftverbôl. Az anyagok lineáris modelljének és folyási egyenletének paraméterei az 1-3. táblázatban találhatóak.

A szimuláció eredményeként kapott redukált feszültség konkrét paraméterek mellett a 9(a) ábrán látható. A szimulációkból egy kezdetben egyenes vonalhoz tartozó csomópontok koordinátáit mentettük, amelyeket a deformációk kiszámításához használtuk fel. A 9(b) ábrán a behálózott lemez és a hengerek hengerlési résben található része látható.

Súrlódási tényezô illesztése a végeselemes módszer és a mérési eredmények összevetésével történt. Az Al6082-es anyag súrlódási tényezője az illesztés alapján 0,075. Az 1. mintára vonatkozóan ez a 10. ábrán látható. A vízszintes tengelyen a lemezvastagság menti koordinátát, a függóleges tengelyen

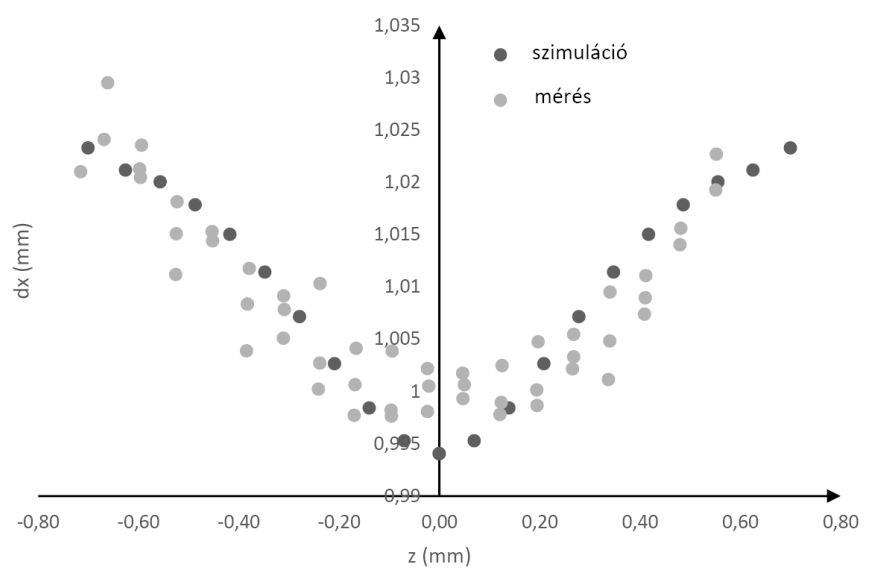

10. ábra: 1. minta pontjainak elmozdulása 0,075 súrlódási tényezó feltételezése mellett 
a lemez elmozdulását ábrázoltuk. Az ábrán a VEM szimuláció eredményének (sötét színú adatsor) és a mérési eredményeknek (világos színú adatsor) összehasonlítása látható. A súrlódási tényezô a többi esetben is 0,07 és 0,08 közötti értékú.

\section{Következtetések}

Munkánk eredményeként sikerült meghatározni a hengerlés során fellépő súrlódási tényező értékét, a hengerlési sebességkülönbség hatását az aszimmetriára, a lemezek átlagos keménységét a kiinduló állapotban és a lemezekben fellépô deformáció eloszlását. A VEM modell felépítését mutattuk be és a hengerelt minta adatait összevetettük a VEM modellezés eredményeivel. VEM modellezés alapján meghatároztuk a lemez és a hengerek közötti súrlódási tényező nagyságát. A továbbiakban a dolgozat eredményei felhasználhatók a szerkezet változásának vizsgálatához, továbbá összevethetôk más módszerek eredményeivel.

\section{Köszönetnyilvánítás}

A munka az EFOP-3.6.1-16-2016-00018 "A felsôoktatási rendszer K+F+I szerepvállalásának növelése intelligens szakosodás által Sopronban és Szombathelyen" címú projekt keretében valósult meg.

\section{Irodalomjegyzék}

[1] Gulyás J., Horváth Á., Illés P., Farkas P., Acélok Hengerlése, Miskolci Egyetem, 2013.

[2] Krállics Gy., Fémek képlékeny alakítása 1. Mechanikai alapfogalmak, anyagszerkezeti változások, egyetemi jegyzet, Miskolci Egyetem, 2019.

[3] Krállics Gy., Szû́cs M., Lénárd J., Súrlódási tényezố meghatározása lemez hideghengerlésnél, Bányászati és Kohászati Lapok - Kohászat 145(2), 2012, pp. 3-6.

[4] Szücs M., Alumínium ötvözetek aszimmetrikus hengerlése, Miskolci Egyetem, 2014.

[5] R. Roumina, C. Sinclair, Deformation Geometry and Through-Thickness Strain Gradients in Asymmetric Rolling, Metallurgical and Materials Transactions A 39, (2008), pp. 2495-2503 CrossRef

[6] C. Boldetti, C. Pinna, I.C. Howard, G. Gutierez, Measurement of deformation gradients in hot rolling of AA3004, Experimental Mechanics 45(6), 2005, pp. 517-525 CrossRef 